\title{
Drumstick (Moringa oleifera): A Miracle Tree for its Nutritional and Pharmaceutic Properties
}

\author{
Diksha Manaware* \\ Department of Horticulture (Vegetable Science), Jawaharlal Nehru Krishi Vishwavidyalaya, \\ Jabalpur (M.P.), India \\ *Corresponding author
}

\begin{abstract}
A B S T R A C T
Keywords

Drumstick

(Moringa oleifera),

Nutritional and

Pharmaceutic

Properties

Article Info

Accepted:

04 August 2020

Available Online:

10 September 2020

Moringa oleifera (M. oleifera) which is commonly known as Drumstick tree belongs to family Moringaceae. It is also called as the horseradish tree, benzolive tree, kelor, marango, mlonge, moonga, mulangay, saijhan, sajna or Ben oil tree. It is called as "Miracle Tree" because of its high nutritional value and medicinal uses. All parts of this plant are renewable sources of tocopherols $(\gamma$ and $\alpha)$, phenolic compounds, $\beta$-carotene, vitamin $\mathrm{C}$ and total proteins, including the essential sulfur amino acids, methionine and cysteine. It is the richest plant source of Vitamins A, B, C, D, E and K. Minerals present in this tree include $\mathrm{K}, \mathrm{Mg}, \mathrm{Ca}, \mathrm{Mn}, \mathrm{Zn}, \mathrm{Cu}$, and $\mathrm{Fe}$. Various parts of Moringa tree possess antitumor, antibacterial, hepatoprotective, circulatory stimulants, antispasmodic, antihypertensive, diuretic, antioxidant, anti-diabetic, cholesterol lowering, antifungal, antiepileptic, antipyretic, antiulcer and anti-inflammatory activities. This review article provides a brief overview about the nutritional importance and medicinal properties of drumstick.
\end{abstract}

\section{Introduction}

Moringa oleifera (M. oleifera) which is commonly known as Drumstick tree (from the long, slender, triangular seed-pods) is an angiospermic, fast-growing, drought-resistant tree which belongs to family Moringaceae. ${ }^{[21]}$ It is also called as the horseradish tree (from the taste of the roots, which resembles horseradish), benzolive tree (from the oil which is derived from the seeds), kelor, marango, mlonge, moonga, mulangay, saijhan, sajna or Ben oil tree. ${ }^{[14,47]}$ All parts of the Moringa tree can be consumed. This plant typically belongs to sub-Himalayan Northen India, Pakistan, Bangladesh and Afghanistan. ${ }^{[48]}$ The Tropical and subtropical area of the world is suitable for the growth of this plant. It is called as "Miracle Tree" because of its high nutritional value and medicinal uses. ${ }^{[47]}$ The genus Moringa includes 13 species distributed in subHimalayan, ranges of India, Sri Lanka, North Eastern and South Western Africa, Madagascar and Arabia. ${ }^{[45]}$ The best known and most widely distributed species is Moringa pterygosperma Gaerthn (syn. Moringa oleifera Lam). 
M. oleifera is a deciduous tree that can reach a height of 10-12 m (32-40 ft) and trunk diameter of $45 \mathrm{~cm}(1.5 \mathrm{ft})$. They have corky gray bark, branching and fern like leaves. The flowers are fragrant and hermaphroditic, surrounded by five unequal, thinly veined, yellowish-white petals. The fruit is a hanging, three-sided brown capsule of 20-45 cm size which holds dark brown, globular seeds with a diameter around $1 \mathrm{~cm}$. The seeds have three whitish papery wings. The drumstick tree is a mixed mating species adapted to outcrossing, although selfing is also possible. It is insectpollinated, with large numbers of insects required for pollination. Fruit set via open pollination is typically $11-15 \%$, while hand pollination yields $62-100 \% .{ }^{[62]}$ The moringa tree is grown mainly in semiarid, tropical, and subtropical areas. It tolerates a wide range of soil conditions, but prefers a neutral to slightly acidic ( $\mathrm{pH} 6.3$ to 7.0), well-drained sandy or loamy soil. It is called as "Miracle Tree" because of its high nutritional value and medicinal uses. All parts of this plant are renewable sources of tocopherols $(\gamma$ and $\alpha)$, phenolic compounds, B-carotene, vitamin $\mathrm{C}$ and total proteins, including the essential sulfur amino acids, methionine and cysteine. ${ }^{[1,}$ ${ }^{17]}$ It is the richest plant source of Vitamins A, B, C, D, E and K. Minerals present in this tree include $\mathrm{K}, \mathrm{Mg}, \mathrm{Ca}, \mathrm{Mn}, \mathrm{Zn}, \mathrm{Cu}$, and Fe. ${ }^{[52]}$ The leaves, pods, seeds, gums, barks and flowers of Moringa are used to relieve mineral and vitamin deficiencies, support a healthy cardiovascular system, promote normal blood-glucose levels, neutralize free radicals (thereby reducing malignancy), provide excellent support of the body's antiflammatory mechanisms, enrich anaemic blood and support immune system. Moringa leaves are good food sources for those suffering from malnutrition due to the high protein and fiber content. ${ }^{[18]}$ Leaves treat with fevers, bronchitis, eye and ear infections, and inflammation of the mucus membrane. ${ }^{[1]}$ Moringa seed cake, obtained as a byproduct of pressing seeds to obtain oil, is used to filter water using flocculation to produce potable water for animal or human consumption.

\section{Pharmaceutic properties of drumstick ( $M$. oleifera)}

Moringa oliefera is often referred as a panacea and can be used to cure more than 300 diseases. ${ }^{[2]}$ Moringa has long been used in herbal medicine by Indians. Various parts of Moringa tree possess antitumor, antibacterial, hepatoprotective, circulatory stimulants, antispasmodic, anti-hypertensive, diuretic, antioxidant, anti-diabetic, cholesterol lowering, antifungal, antiepileptic, antipyretic, antiulcer and anti-inflammatory activities. ${ }^{[45]}$ A number of natural compounds have been isolated from $M$. oleifera leaves including fully acetylated glycosides bearing thiocarbamates, carbamates or nitriles. ${ }^{[16,35]}$ Plant glycosides can be used to cure cancer or chronic conditions such as high cholesterol and atherosclerosis. ${ }^{[8,20]}$ Moringa tree have been proved to contain several phytochemicals having beneficial pharmacological properties with potential medicinal applications. They comprise cholesterol lowering compounds, antiulcer, hypoglycemic, with infectious skin curing, anti-hypertensive, antispasmodic, and anticancer properties. ${ }^{[4]}$ Moringa is used for malnourished children and for improvement of the immune system, against AIDS and HIV linked illnesses. It also contains flavonoids which have anti-carcinogenic, anti-viral and anti-estrogenic activities. [22, 30,31]

\section{Antimicrobial Activity}

Moringa oleifera leaf ethanolic extract had the broadest spectrum of activity on the test bacteria. ${ }^{[7]}$ Antimicrobial activity from the ethanolic extract of leaves, seeds and flowers of Moringa oleifera against microorganisms like Escherichia coli, Klebsiella pneumoniae, 
Enterobacter spp, Proteus mirabilis, Pseudomonas aeroginosa, Salmonella typhi A, Staphylococcus aureus, Streptococcus and Candida albicans. ${ }^{[43]}$ Antibacterial activity from the aqueous, acetone and ethanolic extracts of the leaves of Moringa oleifera. Of the three solvents used, ethanolic extract of the plant demonstrated the highest activity, while the aqueous extract showed the least activity at $100 \mathrm{mg} / \mathrm{ml}$. The activities of the plant extracts were comparable to those of antibiotics, ciprofloxacin, cotrimoxazole and chloramphenicol. ${ }^{[13]}$ The seed extracts of Moringa oleifera were multocida, Escherichia coli, Bacillus subtilis and Staphlocuccus aureus) and fungal (Fusariumsolani and Rhizopus solani) strains. The zones of growth inhibition showed greater sensitivity against the bacterial strains as compared to the fungal strains. ${ }^{[12,24,37]}$

\section{Antiinflammatory Activity}

Aqueous extracts of Moringa oleifera leaves possess anti-inflammatory activity. ${ }^{[33]}$ The phytochemicals like phenolic acids and flavanols present in Moringa are associated with its anti-inflammatory effect. ${ }^{[30,42]}$

\section{Anticancer Activity}

Moringa can be used as an anticancer agent as it is natural, reliable and safe, at established concentrations. It can be used as an antiproliferative agent, thereby inhibiting the growth of cancer cells. Soluble and solvent extracts of leaves have been proven effective as anticancer agents. Furthermore, research papers suggest that the anti-proliferative effect of cancer may be due to its ability to induce reactive oxygen species in the cancer cells. The reactive oxygen species induced in the cells leads to apoptosis. This is further proved by the up regulation of caspase 3 and caspase 9, which are part of the apoptotic pathway.26-28 Moreover, the ROS production by moringa is specific and targets only cancer cells, making it an ideal anticancer agent. The compounds of the leaves that are held responsible for the anticancer activities are glucosinolates, niazimicin and benzyl isothiocyanates. ${ }^{223,25,}$ $28,48,53]$

\section{Antiulcer activity}

Moringa oleifera has also been investigated for its antiulcer activity. There are studies that show that the extract of leaves and fruits of Moringa oleifera has ability to heal chronic gastric ulcers induced via acetic acid. ${ }^{[10,11]}$

\section{Antioxidant Activity}

The antioxidants are popular due to the fact as they fight against free radicals that cause oxidative stress, cell damage, and inflammation. In addition to this, Moringa contains antioxidants called flavonoids, polyphenols, and ascorbic acid in the leaves, flowers, and seeds which are beneficial in many ways. ${ }^{[51]}$ Aqueous, methanolic (70\%), ethanolic extract (80\%) of leaves of Moringa oleifera exhibit strong antioxidant and radical scavenging activity. $\left.{ }^{[31}\right]$ This antioxidant activity of Moringa oleifera leaves is due to presence of Kaemferol. ${ }^{[17,31]}$

\section{Antiurolithiatic Activity}

The root bark of Moringa oleifera Lam. (Moringaceae) acts as an antiurolithiatic agent. This was investigated using an experimentally induced urolithiatic rat model. Hyperoxaluria was induced in rats using $0.75 \%$ ethylene glycol in water. Aqueous (AqE) (200 mg kg $\mathrm{mg}^{-1}$ body weight) and alcoholic extracts (AlcE) (200 mg kg ${ }^{-1}$ body weight) of the root bark of $M$. oleifera were given orally in curative and preventive regimens over a period of 28 days. Both the extracts significantly $(\mathrm{P}<0.001)$ lowered the 
urinary excretion and kidney retention levels of oxalate, calcium and phosphate. ${ }^{[27]}$

\section{Wound healing Activity}

Moringa has blood-clotting properties in its leaves, roots, and seeds that benefit wound healing and can reduce clotting time, which means it reduces the time it takes for scratches, cuts, or wounds to stop bleeding. The ethanolic and ethyl acetate extracts of seeds defines significant antipyretic activity in rats, where ethyl acetate extract of dried leaves presents wound healing activity $(10 \%$ extracts in the form of ointment) on excision, incision and dead space (granuloma) wound models in rats. ${ }^{[51]}$

\section{Antifertility activity}

Zade and dabhadkar, 2015 studied the antifertility effect of the alcoholic extract of Moringa oleifera stem bark in female albino rats. Rats were laprotomised on 10th day of pregnancy and live fetuses were observed in both the horns of the uterus. Rats in group 1 (control) were orally administered, with 0.5 $\mathrm{ml}$ of distilled water once daily while those in group 2 to 4 (experimental groups) were administered 25, 50 and $100 \mathrm{mg} / \mathrm{kg}$ body weight doses of alcoholic extract of $M$. oleifera stem bark respectively. The alcoholic extract of $M$. oleifera stem bark exhibited significant antifertility activity (26.26 to $100 \%){ }^{[55]}$

\section{Anti-asthmatic Activity}

It has been reported a long time ago that Moringa plant can be used for the treatment of asthma. ${ }^{[40]}$ The seed kernels of Moringa oleifera also showed prominent effect in the treatment of bronchial asthma. Also a study showed significant decrease in the severity of asthma symptoms and also concurrent respiratory functions improvement in various human models. ${ }^{[36]}$

\section{Hepatoprotective activity}

Ethanolic extract of leaves and alcoholic extract of seeds of Moringa oleifera showed hepatoprotective effect in Isoniazid, Rifampicin, Pyrazinamide induced liver damage and diclofenac induced hepatic toxicity in rat, respectively. ${ }^{[32]}$

Table.1 Comparison of nutritional value of $M$. oleifera with other common foods

\begin{tabular}{|l|l|}
\hline \multicolumn{1}{|c|}{ Nutrients } & \multicolumn{1}{c|}{ Comparison with other foods } \\
\hline Vitamin A & Four times of carrots $(4 \mathrm{X})$ and thirteen times of spinach (13X) \\
\hline Vitamin B & Four times of pork meat (4X) \\
\hline Vitamin B & Fifty times $(50 \mathrm{X})$ of peanut \\
\hline Vitamin C & Seven times (7X) of oranges \\
\hline Vitamin E & Six times (6X) times of Rapeseed oil \\
\hline Calcium & Four times (4X)times of milk \\
\hline Magnesium & Thirty six (36) times of egg \\
\hline Potassium & Sixty three times (63X) of milk and three times (3X) of banana \\
\hline Iron & Twenty five times(25X) of spinach \\
\hline Protein & Two times (2X) of yogurt \\
\hline Amino acid & Two times (2X) of black vinegar \\
\hline
\end{tabular}


Table.2 Nutritional value and phytochemical constituents of different parts of Drumstick (M. oleifera)

\begin{tabular}{|c|c|c|c|c|}
\hline Plant part & Plant part Picture & Nutritional value & $\begin{array}{l}\text { Phytochemical } \\
\text { constituents }\end{array}$ & Reference \\
\hline Leaves & & $\begin{array}{l}\text { Contains proteins, fiber and various } \\
\text { minerals like } \mathrm{Mg}, \mathrm{Ca}, \mathrm{S}, \mathrm{K} \text {, and Fe, } \\
\text { Vitamins like vitamin-A (Beta-carotene), } \\
\text { vitamin B-choline, vitamin B1-thiamine, } \\
\text { riboflavin, nicotinic acid and ascorbic acid, } \\
\text { Various amino acids like Arg, His, Lys, } \\
\text { Trp, Phe, Thr, Leu, Met, Ile, Val, } \\
\text { Phytochemicals like tannins, sterols, } \\
\text { saponins, trepenoids, phenolics, alkaloids, } \\
\text { Flavanoids like quercitin, isoquercitin, } \\
\text { kaemfericitin, isothiocyanates and } \\
\text { Phenolic compounds such asquercetin, } \\
\text { kaempferol. }\end{array}$ & $\begin{array}{l}\text { Glycoside niazirin, } \\
\text { niazirinin, three mustard } \\
\text { oil glycosides, } \\
\text { 4-[4'-O-acetyl-a-L- } \\
\text { rhmnosyloxy)benzyl] } \\
\text { isothiocynate, niaziminin } \\
\text { A and B. }\end{array}$ & $\begin{array}{l}\text { Faizi et al., } \\
\text { (1994), Faizi et } \\
\text { al., (1995), } \\
\text { Tiloke } \text { et al., } \\
\text { (2013), } \\
\text { Rockwood et al., } \\
\text { (2013), Mbikay } \\
\text { et al., (2012), } \\
\text { Barminas et al., } \\
\text { (1998) }\end{array}$ \\
\hline Root bark & & $\begin{array}{l}\text { Contains Alkaloids like morphine, } \\
\text { moriginine, minerals like calcium, } \\
\text { magnesium and sodium. }\end{array}$ & $\begin{array}{l}\text { 4-(a-L- } \\
\text { rhamnopyranosyloxy)- } \\
\text { benzylglucosinolate }\end{array}$ & $\begin{array}{l}\text { Bennett et al., } \\
\text { (2003), Monera } \\
\text { and Maponga } \\
(2012)\end{array}$ \\
\hline Flowers & & Contains $\mathrm{Ca}, \mathrm{K}$, amino acids and nectar. & $\begin{array}{l}\text { D- mannose, D- glucose, } \\
\text { protein, ascorbic acid, } \\
\text { polysaccharide }\end{array}$ & $\begin{array}{l}\text { Pramanik et al., } \\
\text { (1998), Barminas } \\
\text { et al., (1998), } \\
\text { Sutalangka et al., } \\
\text { (2013) }\end{array}$ \\
\hline Pods & & $\begin{array}{l}\text { Contains lipids, non-structural } \\
\text { carbohydrates, protein, fiber, ash and } \\
\text { various fatty acids like linoleic acid etc. }\end{array}$ & $\begin{array}{l}\text { Nitriles, isothiocyanate, } \\
\text { thiocarbanates, } \\
\text { 0-ethyl-4-[(a-1 } \\
\text { rhamnosyloxy)-benzyl] } \\
\text { carbamate, methyl-p- } \\
\text { hydroxybenzoate and } \beta \\
\text { sitosterol }\end{array}$ & $\begin{array}{l}\text { Faizi et al., } \\
\text { (1994), Faizi et } \\
\text { al., (1995), } \\
\text { Fuglie et al., } \\
\text { (2005), Barminas } \\
\text { et al., (1998) }\end{array}$ \\
\hline Seeds & & $\begin{array}{l}\text { Contains oleic acid (Ben oil), an antibiotic } \\
\text { called pterygospermin, Phytochemicals } \\
\text { like tannins, saponin, phenolics,quercetin, } \\
\text { phytate, flavanoids, terpenoids, lectins, } \\
\text { kaempferol, Antioxidants such as vitamin } \\
\text { C, } \beta \text {-carotene, } \alpha \text { and } \gamma \text {-tocopherol, } \beta \text { - } \\
\text { sitosterol, vitamin A, alkaloids, } \\
\text { glucosinolates, and isothiocyanates, Fatty } \\
\text { acids like Linoleic acid, linolenic acid, } \\
\text { behenic acid. }\end{array}$ & $\begin{array}{l}\text { Crude protein, crude fat, } \\
\text { carbohydrate, methionine, } \\
\text { cysteine, 4-(a-L- } \\
\text { rhamnopyranosyloxy)- } \\
\text { benzylglucosinolate, } \\
\text { benzylglucosinolate, } \\
\text { moringyne, mono- } \\
\text { palmitic and di-oleic } \\
\text { triglyceride, Vitamin A, } \\
\text { beta carotene (precursor } \\
\text { of Vitamin A) }\end{array}$ & $\begin{array}{l}\text { Bennett et al., } \\
\text { (2003), } \\
\text { Rockwood et al., } \\
\text { (2013), Fahey et } \\
\text { al., (2005), } \\
\text { Thurber and } \\
\text { Fahey (2010) }\end{array}$ \\
\hline
\end{tabular}


Table.3 Nutrient values of leaves and pods of Moringa oleifera

\begin{tabular}{|c|c|c|}
\hline Principle & Nutrient value-Leaves & Nutrient value-Pods \\
\hline \multicolumn{3}{|l|}{ Vitamins } \\
\hline Folates & $40 \mu \mathrm{g}(10 \%)$ & $44 \mu \mathrm{g}(11 \%)$ \\
\hline Niacin & $2.220 \mathrm{mg}(14 \%)$ & $0.680 \mathrm{mg}(4 \%)$ \\
\hline Pyridoxine & $1.200 \mathrm{mg}(92 \%)$ & $0.120 \mathrm{mg}(9 \%)$ \\
\hline Riboflavin & $0.660 \mathrm{mg}(51 \%)$ & $0.074 \mathrm{mg}(6 \%)$ \\
\hline Thiamin & $0.257 \mathrm{mg}(21.5 \%)$ & $0.053 \mathrm{mg}(4.5 \%)$ \\
\hline Vitamin A & 7564 IU $(252 \%)$ & $74 \mathrm{IU}(2.5 \%)$ \\
\hline Vitamin C & $51.7 \mathrm{mg}(86 \%)$ & $141 \mathrm{mg}(235 \%)$ \\
\hline \multicolumn{3}{|l|}{ Electrolytes } \\
\hline Sodium & $9 \mathrm{mg}(0.5 \%)$ & $42 \mathrm{mg}(3 \%)$ \\
\hline Potassium & $337 \mathrm{mg}(7 \%)$ & $461 \mathrm{mg}(10 \%)$ \\
\hline \multicolumn{3}{|l|}{ Minerals } \\
\hline Calcium & $185 \mathrm{mg}(18.5 \%)$ & $30 \mathrm{mg}(3 \%)$ \\
\hline Iron & $4.00 \mathrm{mg}(50 \%)$ & $0.36 \mathrm{mg}(4.5 \%)$ \\
\hline Magnesium & $147 \mathrm{mg}(37 \%)$ & $45 \mathrm{mg}(11 \%)$ \\
\hline Phosphorus & $112 \mathrm{mg}(20 \%)$ & $50 \mathrm{mg}(9 \%)$ \\
\hline Selenium & $0.9 \mu \mathrm{g}(1.5 \%)$ & $8.2 \mu \mathrm{g}(15 \%)$ \\
\hline Zinc & $0.60 \mathrm{mg}(5 \%$ & $0.45 \mathrm{mg}(4 \%)$ \\
\hline Energy & $64 \mathrm{Kcal}(3 \%)$ & $37 \mathrm{Kcal}(2 \%)$ \\
\hline Carbohydrates & $8.28 \%(6 \%)$ & $8.53 \mathrm{~g}(6.5 \%)$ \\
\hline Protein & $9.40 \mathrm{~g}(17 \%)$ & $2.10 \mathrm{~g}(4 \%)$ \\
\hline Total Fat & $1.40 \%(7 \%)$ & $0.20 \mathrm{~g}(1 \%)$ \\
\hline Cholesterol & $0 \mathrm{mg}(0 \%)$ & $0 \mathrm{mg}(0 \%)$ \\
\hline Dietary Fiber & $2.0 \mathrm{~g}(5 \%)$ & $3.2 \mathrm{~g}(8 \%)$ \\
\hline
\end{tabular}

Table.4 Medicinal uses of different parts of M. oleifera

\begin{tabular}{|c|c|c|}
\hline Plant Parts & Medicinal uses & Reference \\
\hline Leaves & $\begin{array}{l}\text { Treat asthma, hyperglycemia, Dyslipidemia, flu, heart burn, } \\
\text { syphilis, malaria, pneumonia, diarrhea, headaches, scurvy, } \\
\text { skin diseases, bronchitis, eye and ear infections Also } \\
\text { reduces, blood pressure and cholesterol and acts as an } \\
\text { anticancer, Antioxidant, antimicrobial, anti-atherosclerotic } \\
\text { and ant diabetic agents, neuro protectant }\end{array}$ & $\begin{array}{l}\text { Jung, (2014), Monera and } \\
\text { Maponga,(2012) }\end{array}$ \\
\hline Root bark & $\begin{array}{l}\text { Act as a cardiac stimulant, antiulcer and anti-inflammatory } \\
\text { agent }\end{array}$ & $\begin{array}{l}\text { Monera and Maponga, } \\
(2012)\end{array}$ \\
\hline Flower & $\begin{array}{l}\text { Act as hypocholesterolemic, anti-arthritic agents can cure } \\
\text { urinary problems and cold }\end{array}$ & Sutalangka et al., (2013) \\
\hline Pod & Treat diarrhea, liver and spleen problems, and joint pain. & Fuglie, (2005) \\
\hline Seed & $\begin{array}{l}\text { Treat hyperthyroidism, Chrohn's disease, antiherpes- } \\
\text { simplex virus arthritis, rheumatism, gout, cramp, epilepsy } \\
\text { and sexually transmitted diseases, can act as antimicrobial } \\
\text { and anti-inflammatory agents }\end{array}$ & Thurber and Fahey, (2010) \\
\hline
\end{tabular}




\section{Antiepileptic Activity}

Methanolic extract of Moringa oleifera leaves were investigated its anti-convulsant activity using Pentylenetetrazole (PTZ) and maximum electric shock (MES) on male albino mice. ${ }^{[3]}$

\section{Cardiovascular activity}

Moringa leaf powder has heart-healthy benefits, particularly to control blood lipid, the prevention of plaque formation in the arteries, and reduced cholesterol levels. The great combination of diuretic along with lipid and blood pressure lowering components make this plant incredibly beneficial in cardiovascular disorders. ${ }^{[51]}$

In conclusion the drumstick ( $M$. oleifera) is highly valued for its indispensable medicinal properties and nutritional benefits. Moringa oleifera has enormous potential uses but it is very less explored. It has several medicinal properties like Anti Diabetic, Anti Asthmatic, Hepatoprotective, antiinflammatory, antipyretic, Analgesic activity, Hypocholesterolemic effect, AntiOxidant, Anti-Microbial, Anti-Cancer, Water Purification properties. It is also use as a good source of animal and bird feed and food forticant. The study revealed that almost all parts of drumstick such as leaves, root bark, flowers, pods, seeds are used extensively in traditional medicines. The above mentioned nutritional and pharmaceutics properties of $M$. oleifera, made it a "Tree of Life".

\section{References}

1. Abbas RK, Elsharbasy FS and Fadlelmula AA. (2018). Nutritional Values of Moringa oleifera, Total Protein, Amino Acid, Vitamins, Minerals, Carbohydrates, Total Fat and Crude Fiber, under the Semi-Arid
Conditions of Sudan. Journal of Microbial \& Biochemical Technology, 10(2): 56-58.

2. Akhouri S, Prasad A and Ganguly S. (2013). Moringa oleifera Leaf Extract Imposes Better Feed Utilization in Broiler Chicks. Journal of Biology and Chemical Research. 30 (2): 447-450.

3. Amrutia JN. (2011). Anticonvulsant activity of Moringa oleifera leaves. International Research Journal of Pharmacy, 2(7):160 -162.

4. Anwar F, Latif S, Ashraf M and Gilani AH. (2007). Moringa oleifera: A Food Plant with Multiple Medicinal Uses. Phytotherapy Research, 21: 17-25.

5. Barminas JT, Charles M, Emmanuel D. (1998). Mineral composition of nonconventional leafy vegetables. Plant Foods for Human Nutrition, 53(1):2936.

6. Bennett RN, Mellon F A, Foidl N, Pratt JH, Du pont MS, Perkins L and Kroon PA. (2013). Profiling glucosinolates and phenolics in vegetative and reproductive tissues of the multi-purpose trees Moringa oleifera L. and Moringastenopetala L. Journal of Agricultural and Food Chemistry, 51 (12): 3546-3553.

7. Bukar A, Uba A and Oyeyi TI.(2010). Antimicrobal profile of Moringa oleifera Lam. Extracts against some food- borne microorganisms.Bayero Journal of Pure and Applied Sciences, 3(1): 43 -48.

8. Chumark P, Khunawat P, Sanvarinda Y and Phornchirasilp S. (2008). The in vitro and ex vivo antioxidant properties, hypolipidaemic and antiatherosclerotic activities of water extract of Moringa oleifera Lam. Leaves. Journal of Ethnopharmacology, 116(3):439-46.

9. Das D, Sahu D, Baruah D, Ray C, Rai S and Hazra J. (2017). Moringa olifera (shigru): a miracle tree for its nutritional, ethnomedicinal and therapeutic importance. International Journal of Development Research, 07(11): 16823- 
16827.

10. Devaraj VC, Asad $M$ and Prasad S. (2007). Effect of leaves and fruits of Moringa oleifera on gastric and duodenal ulcers. Pharmaceutical Biotechnology, 45:332-338.

11. Devaraj VC, Gopala Krishna B. (2013). Antiulcer activity of a polyherbal formulation (PHP) from Indian medicinal plants. Chinese journal of Natural Medicines, 11(2):145-148.

12. Dewangan G, Koley KM, Vadlamudi VP, Mishra A, Poddar A and Hirpurkar SD. (2010). Antibacterial activity of Moringa oleifera (drumstick) root bark. Journal of Chemical and Pharmaceutical Research, 2(6):424-428.

13. Doughari JH, Pukuma MS, De N. (2007).Antibacterial effects of Balanites aegyptiaca L. Drel. And Moringa oleifera Lam. on Salmonella typhi. African Journal of Biotechnology, 6(19), 2212- 2215.

14. Fahey JW. (2005). Moringa oleifera: A Review of the Medical Evidence for Its Nutritional, Therapeutic, and Prophylactic Properties. Part 1. Trees for Life Journal, 1:5.

15. Faizi S, Siddiqui BS, Saleem R, Siddiqui $S$ and Aftab K. (1994). Isolation and structure elucidation of new nitrile and mustard oil glycosides from Moringa oleifera and their effect on blood pressure. Journal of Natural Products, 57(9): 1256-1261.

16. Faizi S, Siddiqui BS, Saleem R, Siddiqui S, Aftab K, Gilani AH. (1995). Fully acetylated carbamate and hypotensive thiocarbamate glycosides from Moringa oleifera. Phytochemistry, 38:957-963.

17. Ferreira PMP, Farias DF, Oliveira JTA, Carvalho AFU. (2008). Moringa oleifera: bioactive compounds and nutritional potential. Brazilian Journal of Nutrition, 21(4):431-437.

18. Fuglie (2005). The Moringa Tree: A local solution to malnutrition Church World Service in Senegal.
19. Ganatra TH, Joshi UH, Bhalodia PN, Desai TR and Tirgar PR. (2012). A panoramic view on pharmacological, nutritional, therapeutic and prophylactic values of Moringa oleifera Lam. International Research Journal of Pharmacy, 3(6): 1-7.

20. Ghasi S, Nwobodo EO, EzekwesiliOfili JO. (2000). Hypocholesterolemic effects of crude extract of leaf of Moringa oleifera Lam in high-fat diet fed wistar rats. Journal of Ethnophramacology, 69(1):21-5.

21. Hassan FAG, Ibrahim MA. (2013). Moringa oleifera: Nature is Most Nutritious and MultiPurpose Tree. International Journal of Scientific and Research Publications. 3(4): 1-5.

22. Havsteen BH. (2002). The biochemistry and medical significance of the flavonoids. Pharmacology and Therapeutics, 96: 67-202.

23. Hermawan, Nur KA, Sarmoko, Dewi D, Putri P and Meiyanto E. (2012). Ethanolic extract of Moringa oleifera increased cytotoxic effect of doxorubicin on HeLa cancer cells. Journal of Natural Remedies, 12(2):108-114.

24. Jabeen R, Shahid M, Jamil A and Ashraf M. (2008).Microscopic evaluation of the antimicrobial activity of seed extracts of Moringa oleifera. 40(4): 1349-1358.

25. Jung L. (2014). Soluble Extract from Moringa oleifera Leaves with a New Anticancer Activity. PLoS One, 9(4): 110.

26. Kalpana S, Moorthi S and Kumari S. (2013). Antimicrobial activity of different extracts of leaf of Moringa oleifera (Lam.) against gram positive and gram negative bacteria. International Journal of Current Microbiology Applied.Science, 2(12): 514-518.

27. Karadi RV, Palkar MB, Gaviraj EN, Gadge NB, Mannur VS and Alagawadi KR. (2008). Antiurolithiatic Property of Moringa oleifera Root Bark. Pharmaceutical Biology, 46(12): 861- 
865.

28. Leelawat S, Leelawat L. (2014). Moringaolefiera extracts induce cholangiocarcinoma cell apoptosis by induction of reactive oxygen species production. International Journal of Pharmacognosy and Phytochemical Research, 6(2):183-189.

29. Mibikay M. (2012). Therapeutic potential of Moringa oleifera leaves in chronic hyper glycemia and dyslipidemia: A review. Frontiers in Pharmacology, 13:1-12.

30. Middleton Jr., E.; Kandaswami, C.; Theoharides, T.C. (2000). The effects of plantflavonoids on mammalian cells: implications for inflammation, heart disease, and cancer. Pharmacological Reviews, 52: 673-751.

31. Miean HK, Mohamed S. (2001). Flavonoid (Myricetin, Quercetin, Kaempferol, Luteolin, and Apigenin) Content of Edible Topical Plants. Journal of Agricultural and Food Chemistry, 49: 3106-3112.

32. Mishra G, Singh P, Verma R, Kumar S. (2011). Traditional uses, phytochemistry and pharmacological properties of Moringa oleifera plant: An overview. Scholars Research Library, Der Pharmacia Lettre, 3(2): 141-164.

33. Mittal A, Sharma M, David A, Vishwakarma P, Saini M, Goel M, Saxena KK. (2017). An experimental study to evaluate the anti-inflammatory effect of Moringa oleifera leaves in animal models. International Journal of Basic \& Clinical Pharmacology. 6(2):452-457.

34. Monera TG and Maponga CC. (2012). Prevalence and patterns of Moringa oleifera use among HIV positive patients in Zimbabwe: a cross- sectional survey. Journal of public health in Africa. 3(1):6-8.

35. Murakami A, Kitazono Y, Jiwajinda S, Koshimizu K, Ohigashi H. (1998). Niaziminin, a thiocarbamate from the leaves of Moringa oleifera, holds a strict structural requirements for inhibition of tumor- promotor- induced Epstein-Barr virus activation. Planta Medica, 64: 319323.

36. Nambiar VS, Bhadalkar $\mathrm{K}$ and Daxini M. (2003). Drumstick leaves as source of vitamin A in ICDS-SFP. The Indian Journal of Pediatrics, 70:383-387.

37. Pal SK, Mukherjee PK, Saha K, Pal M and Saha BP. (1995). Antimicrobial actions of the leaf extract of Moringa oleifera LAM. Ancient Science of Life, 15(3): 197 - 199.

38. Patel S, Thakur AS, Chandy A and Manigauha A. (2010). Moringa oleifera: A Review of There Medicinal and Economical Importance to the Health and Nation. Drug Invention Today, 2(7): 339-342.

39. Pramanik A and Islam SS. (1998). Chemical investigation of aqueous extract of the mature and premature flowers of Moringa oleifera and Structural studies of a polysaccharide isolated from its premature flowers. Indian Journal of Chemistry, 37B: 676682.

40. Pullakhandam R, Failla ML. (2005). Micellarization and intestinal cell uptake of beta-carotene and lutein from drumstick (Moringa oliefera) leaves. Journal of Medicinal Food, 10(2):252-7.

41. Rajbhar YP, Rajbhar G, Rawat PL, ShardulyaShukla S, Kumar M. (2008). Grow Moringa (Moringa oleifera), the miracle tree on the earth. Horticulture International Journal, 2(4):166-172.

42. Razis AFA, Ibrahim DM, Kntayya SB. (2014). Health benefits of Moringa oleifera. Asian pacific journal of cancer prevention, 15 (20): 8571-8576.

43. Renitta RE, Anitha J and Napolean P. (2009). Isolation, analysis and identification of phytochemicals of antimicrobial activity of Moringa oleifera Lam. Current Biotica, 3(1):3337. 
44. Rockwood L, Anderson BG and Casamatta DA. (2013). Potential uses of Moringa oleifera and an examination of antibiotic efficacy. International Journal of Phytotherapy Research, 3(1):61-71.

45. Sahay S, Yadav U, Srinivasamurthy S. 2017. Potential of Moringa oleifera as a functional food ingredient: A review. International Journal of Food Science and Nutrition, 2 (5): 31-37.

46. Sandeep G, Anitha T, Vijayalatha KR, Sadasakthi A. (2019). Moringa for nutritional security (Moringa oleifera Lam.). International Journal of Botany Studies, 4(1): 21-24.

47. Singh L, Jyoti and Singh J. (2019). Medicinal and Nutritional Values of Drumstick Tree (Moringa oleifera) - A Review. International Journal of Current Microbiology Applied.Science, 8(5): 1965-1974.

48. Sodhi G, Das S, Mazumder A and Rana SK. (2019). Ethnopharmacological Review of Drum Stick (Moringa oleifera): Prevalently Used As An Alternative Medicine. Research Journal of Pharmaceutical, Biological and Chemical Sciences, 10(3): 458-468.

49. Sutalangka C, Wattanathorn J, Muchimapura S and Thukhammee W. (2013). Moringa oleifera mitigates memory impairment and neurodegeneration in animal model of age- related dementia. Oxidative Medicine and Cellular Longevity. 7(2):1-9.

50. Thakur SB, Bajagain A. (2020). Moringa: alternative for the food security, climate resilience and livelihood improvement in Nepal. International Journal of Research

\section{How to cite this article:}

DikshaManaware. 2020. Drumstick (Moringa oleifera): A Miracle Tree for its Nutritional and Pharmaceutic Properties. Int.J.Curr.Microbiol.App.Sci. 9(09): 41-50.

doi: https://doi.org/10.20546/ijcmas.2020.909.005
Granthaalayah, 8 (3): 190-200.

51. Thapa K, Poudel $M$ and Adhikari P. (2019). Moringa oleifera: A Review Article on Nutritional Properties and its Prospect in the Context of Nepal. Acta Scientific Agriculture, 3(11) 47-54.

52. Thurber MD and Fahey JW. (2010). Adoption of Moringa oleifera to combat under- nutrition viewed through the lens of the diffusion of innovations theory. Ecology of Food and Nutrition, 48(1):113.

53. Tiloke C, Phulukdaree A, Chuturgoon AA. (2013). The antiproliferative effect of Moringa oleifera crude aqueous leaf extract on cancerous human alveolar epithelial cells. BMC Complement Alternative Medicine, 13:226- 233.

54. Vieira GHF, Mourão JA, Angelo AM, Costa RA and Vieira RHSF. (2010). Antibacterial effect (in vitro) of Moringa oleifera and Annonamuricata against gram positive and gram negative bacteria, 52(3):129-132.

55. Zade V and Dabhadkar D. (2015). Antifertility effect of alcoholic extract of Moringa oleifera stem bark on estrous cycle and estrogenic activity of female albino rat. American Journal of Advanced Drug Delivery. 3(3): 223-235.

56. Zhang J, Mengfei L, Hanbin C, Qin Z, $\mathrm{Vu}$ Ngoc L and Xiaoyang C. (2017). Floral biology and pistil receptivity of the drumstick tree (Moringa oleifera Lam.). pp 1- 13. 